\title{
High glucose induces caspase-independent cell death in retinal neural cells
}

\author{
A.R. Santiago, ${ }^{\mathrm{a}, \mathrm{b}}$ A.J. Cristóvão, ${ }^{\mathrm{a}, \mathrm{c}}$ P.F. Santos, ${ }^{\mathrm{a}, \mathrm{c}}$ C.M. Carvalho, ${ }^{\mathrm{a}, \mathrm{c}}$ and A.F. Ambrósio ${ }^{\mathrm{a}, \mathrm{b}, *}$ \\ ${ }^{\mathrm{a}}$ Center for Neuroscience and Cell Biology, Department of Zoology, University of Coimbra, 3004-517 Coimbra, Portugal \\ ${ }^{\mathrm{b}}$ Center of Ophthalmology of Coimbra, Institute of Biomedical Research on Light and Image (IBILI), Faculty of Medicine, University of Coimbra, \\ 3000-548 Coimbra, Portugal \\ ${ }^{\mathrm{c}}$ Department of Zoology, University of Coimbra, 3004-517 Coimbra, Portugal
}

Received 20 July 2006; revised 6 October 2006; accepted 29 October 2006

Available online 16 December 2006

\begin{abstract}
Diabetic retinopathy is a leading cause of blindness among adults in the western countries. It has been reported that neurodegeneration may occur in diabetic retinas, but the mechanisms underlying retinal cell death are poorly understood. We found that high glucose increased the number of cells with condensed nuclei and the number of TUNELpositive cells, and caused an increase in the translocation of phosphatidylserine to the outer leaflet of the plasma membrane, indicating that high glucose induces apoptosis in cultured retinal neural cells. The activity of caspases did not increase in high glucose-treated cells, but apoptosis-inducing factor (AIF) levels decreased in the mitochondria and increased in the nucleus, indicating a translocation to the nucleus where it may cause DNA fragmentation. These results demonstrate that elevated glucose induces apoptosis in cultured retinal neural cells. The increase in apoptosis is not dependent on caspase activation, but is mediated through AIF release from the mitochondria. (C) 2007 Elsevier Inc. All rights reserved.
\end{abstract}

Keywords: Apoptosis; Mitochondria; Retinopathy; Apoptosis-inducing factor (AIF); Diabetes

\section{Introduction}

Diabetic retinopathy (DR) is a leading cause of blindness among adults in the western countries. This disease is usually considered a vascular disease, but several evidences have demonstrated that retinal neurodegeneration may also occur. The vascular features of DR are well documented, and include basement membrane thickening, the formation of microaneurysms, and loss of pericytes and endothelial cells (Cai and Boulton, 2002). Loss of color and contrast sensitivity, and alterations in the electroretinograms of human patients with diabetes (Sakai et al.,

* Corresponding author. Center of Ophthalmology of Coimbra, IBILI, Celas, 3000-548 Coimbra, Portugal. Fax: + 351239480280.

E-mail address: fambrosio@ibili.uc.pt (A.F. Ambrósio).

Available online on ScienceDirect (www.sciencedirect.com).
1995) are early signs of retinal neural dysfunction. Apoptosis of retinal neurons and retinal thinning have been noted histologically in diabetes (Barber et al., 1998; Martin et al., 2004; Barber et al., 2005), and an increase in caspase activation was already demonstrated (Mohr et al., 2002; Krady et al., 2005). However, despite several evidences showing retinal neurodegeneration, the mechanisms underlying the loss of retinal neurons during diabetes are not well elucidated yet.

Apoptosis, or programmed cell death, occurs as a physiological phenomenon during normal embryonic development and in the cell turnover throughout life. However, apoptosis has also been implicated in several neurodegenerative diseases. Caspases are cysteine proteases that mediate apoptotic cell death in a variety of cells, including neurons. Caspases can be activated through extrinsic or intrinsic pathways. The latter requires the release of cytochrome $c$ from mitochondria, which recruits Apaf-1 and procaspase-9, forming the apoptosome. As a consequence, caspase-9 is activated and subsequently other caspases, including caspase-3, are activated (Zou et al., 1997). This activation of caspases contributes to cell death through the degradation of DNA repair enzymes and structural elements such as cytoskeleton, and also leads to activation of chromosomal endonucleases.

There is no doubt that caspases play a central role in many apoptotic mechanisms. However, increasing evidences indicate that apoptotic features can also be found in cells where caspase activation is not detected or where caspase inhibitors have been employed (Leifer et al., 1991; Lavoie et al., 1998; Okuno et al., 1998; Borner and Monney, 1999). In this form of cell death, in which cell death is not mediated by caspase activation, two endonucleases, apoptosisinducing factor (AIF) and endonuclease G, are proposed to translocate from the mitochondrial intermembrane space to the nucleus, where they are involved in DNA fragmentation and chromatin condensation (Susin et al., 1999; Li et al., 2001). In the absence of apoptotic signals, AIF, a $57-\mathrm{kDa}$ protein, is usually confined to the mitochondrial intermembrane space (Lorenzo et al., 1999; Susin et al., 1999; Daugas et al., 2000). However, when apoptosis is induced it translocates to the nucleus, causing peripheral 
chromatin condensation and large-scale DNA fragmentation (Susin et al., 1999).

A sustained increase in intracellular calcium concentration $\left(\left[\mathrm{Ca}^{2+}\right]_{\mathrm{i}}\right)$ is known to cause cell dysfunction and cell death (Duchen, 2000). Since we previously found that in high glucosetreated cells calcium homeostasis is deregulated (Santiago et al., 2006a), which may contribute for retinal neural cell degeneration, the purpose of this study was to investigate whether elevated glucose causes cell death in retinal neural cells. The identification of the mechanisms underlying retinal neurodegeneration under high glucose conditions was also addressed.

Our experiments revealed that high glucose induces apoptotic cell death by a caspase-independent mechanism, mediated by AIF mito-nuclear translocation.

\section{Materials and methods}

\section{Materials}

Fetal bovine serum was purchased from Biochrom (Cambridge, UK). Trypsin (USP grade) was purchased from Gibco (GIBCO BRL, Life Technologies, Scotland, UK). Z-DEVD-AFC was purchased from Calbiochem (Darmstadt, Germany). Hoechst 33342 dye was obtained from Molecular Probes (Eugene, OR, USA). The rabbit caspase-3 antibody was from Cell Signaling Technology (Danvers, MA, USA), the mouse monoclonal antibody anti-AIF was from Santa Cruz Biotechnology Inc. (Santa Cruz, CA, USA), the rabbit anti-MAP2 antibody and the mouse anti-Lamin B antibodies were obtained from Chemicon (Temecula, CA, USA), the mouse monoclonal antibody anti- $\alpha$-tubulin was from Sigma-Aldrich (St. Louis, MO, USA). The polyvinylidene difluoride (PVDF) membranes, the alkaline phosphatase-linked anti-mouse secondary antibody and the enhanced chemifluorescence $(\mathrm{ECF})$ reagent were obtained from GE Healthcare (Buckinghamshire, UK). Other reagents used in immunoblotting experiments were purchased from Bio-Rad (Hercules, CA, USA). All other reagents were from SigmaAldrich or from Merck KGaA (Darmstadt, Germany).

\section{Primary cultures of rat retinal neural cells}

All procedures involving animals were conducted in accordance with the Association for Research in Vision and Ophthalmology (ARVO) statement for the use of animals in ophthalmic and vision research. Retinal cell cultures were prepared as previously described (Santiago et al., 2006b). Briefly, 3- to 5-day-old Wistar rat pups were anesthetized by intraperitoneal injection of ketamine $(0.05 \mathrm{ml}$ of a $100 \mathrm{mg} / \mathrm{ml}$ solution) before decapitation, and the retinas were dissected under sterile conditions, using a light microscope, in $\mathrm{Ca}^{2+}$ and $\mathrm{Mg}^{2+}$-free Hank's balanced salt solution (in mM: $137 \mathrm{NaCl}, 5.4$ $\mathrm{KCl}, 0.45 \mathrm{KH}_{2} \mathrm{PO}_{4}, 0.34 \mathrm{Na}_{2} \mathrm{HPO}_{4}, 4 \mathrm{NaHCO}_{3}, 5$ glucose; $\mathrm{pH} 7.4$ ). The retinas were digested with $0.05 \%$ trypsin $(\mathrm{w} / \mathrm{v})$ for $15 \mathrm{~min}$ at $37{ }^{\circ} \mathrm{C}$. After dissociation, the cells were pelleted by centrifugation and resuspended in Eagle's minimum essential medium (MEM) supplemented with $26 \mathrm{mM} \mathrm{NaHCO} 3,25 \mathrm{mM}$ HEPES, $10 \%$ heatinactivated fetal bovine serum, penicillin $(100 \mathrm{U} / \mathrm{ml})$ and streptomycin $(100 \mu \mathrm{g} / \mathrm{ml})$. The cells were plated at a density of $2.0 \times 10^{6}$ cells $/ \mathrm{cm}^{2}$ on 24 -well plates for MTT viability assay, on $35 \mathrm{~mm}$ Petri dishes for measuring the intracellular ATP levels, on $60 \mathrm{~mm}$ Petri dishes for caspase-3-like enzymes activity and Western blot analysis, and on glass coverslips for Hoechst staining, annexin $\mathrm{V}$ staining, TUNEL staining, FAM-VAD-FMK staining and immunocytochemistry, all coated with poly-D-lysine $(0.1 \mathrm{mg} / \mathrm{ml})$. The cells were maintained at $37{ }^{\circ} \mathrm{C}$ in a humidified atmosphere of $5 \% \mathrm{CO}_{2} /$ air. After 2 days in culture, the cells were incubated with $25 \mathrm{mM}$ D-glucose (yielding a total $30 \mathrm{mM}$ glucose) or with $25 \mathrm{mM}$ D-mannitol (plus $5 \mathrm{mM}$ glucose), which was used as an osmotic control, and maintained for further 7 days. The concentration of glucose in control conditions was $5 \mathrm{mM}$.

\section{Determination of extracellular glucose concentration}

The concentration of glucose in the culture medium, 7 days after incubation with high glucose or mannitol, was determined using a colorimetric kit (BioSystems; Barcelona, Spain) following the manufacturer's instructions. The medium was collected from control, high glucose- and mannitol-treated cell cultures.

Assessment of cell viability

The 3-(4,5-dimethylthiazol-2-yl)-2,5-diphenyltetrazolium bromide (MTT) assay was used for the assessment of cell viability. MTT, when taken up by living cells, is converted from a yellow- to a water-insoluble blue-colored precipitate by cellular dehydrogenases (Mosmann, 1983). Briefly, cells were washed with saline buffer (in mM: $132 \mathrm{NaCl}, 4 \mathrm{KCl}, 1.4 \mathrm{MgCl}_{2}, 1.4 \mathrm{CaCl}_{2}, 6$ glucose, 10 HEPES; $\mathrm{pH} 7.4)$, and then saline buffer with MTT $(0.5 \mathrm{mg} / \mathrm{ml})$ was added to the cultures and incubated for $1 \mathrm{~h}$ at $37^{\circ} \mathrm{C}$ in the incubation chamber. The precipitated dye was dissolved in $0.04 \mathrm{M} \mathrm{HCl}$ in isopropanol and quantitated colorimetrically (absorbance at $570 \mathrm{~nm}$ ). All experiments were carried out in triplicate.

\section{Determination of ATP levels}

Intracellular ATP levels were determined by reverse-phase HPLC, after cell extraction, as described previously (Stocchi et al., 1985). Cells were lysed in $0.3 \mathrm{M}$ perchloric acid and then collected. Extraction was followed by centrifugation at $15800 \times \mathrm{g}$ for $5 \mathrm{~min}$, at $4{ }^{\circ} \mathrm{C}$. The pellet was solubilized in $0.1 \mathrm{M} \mathrm{NaOH}$ for total protein analysis by the Bradford/Bio-Rad method. The supernatant was neutralized with $3.3 \mathrm{M} \mathrm{KOH}$ in $1.67 \mathrm{M}$ Tris and centrifuged at $15800 \times \mathrm{g}$ for $10 \mathrm{~min}$. The potassium perchlorate precipitate was discarded and the resulting supernatants were stored at $-80^{\circ} \mathrm{C}$. ATP content was determined by reverse-phase HPLC using a Beckman System Gold, consisting of a binary pump (126 Binary Pump Model) with a 166 Variable UV detector, computer-controlled. A Lichrospher $100 \mathrm{Rp}-18$ (5 $\mu \mathrm{m})$ and guard column (Merck) were used. The mobile phase (100 mM KH${ }_{2} \mathrm{PO}_{4}, 1 \%$ methanol; $\mathrm{pH} 6.0$ ) was used at a flow rate of $1.1 \mathrm{ml} / \mathrm{min}$. Absorbance was monitored at $254 \mathrm{~nm}$. Peak identity was determined by comparison with the retention time of standards. The amount of ATP was determined by a concentration standard curve, and ATP content values were normalized according to the protein concentration for each sample.

\section{Nuclear morphology assay}

The morphology of nuclei was analysed by fluorescence microscopy using Hoechst 33342 dye. Cells were gently washed in phosphate-buffered saline (PBS; in mM: $137 \mathrm{NaCl}, 2.7 \mathrm{KCl}, 10$ $\mathrm{Na}_{2} \mathrm{HPO}_{4}, 1.8 \mathrm{KH}_{2} \mathrm{PO}_{4} ; \mathrm{pH} 7.4$ ) and fixed in $4 \%$ paraformaldehyde for $30 \mathrm{~min}$ at room temperature. Cells were then incubated with $2 \mu \mathrm{g} /$ $\mathrm{ml} \mathrm{Hoechst} 33342$ in PBS for $5 \mathrm{~min}$. Cells were rinsed and mounted using fluorescent mounting medium (Dako; Glostrup, Denmark). 
Fluorescence of stained chromatin was examined and the fragmented and condensed chromatin was scored using a Zeiss Axioshop 2 Plus microscope. For each preparation, 5-7 random fields were counted.

\section{Terminal transferase dUTP nick end labeling (TUNEL) staining}

TUNEL was performed in cultured retinal neural cells with horseradish peroxidase detection (TUNEL-HRP), following the instructions provided by the manufacturer (Promega). Cells were washed in PBS and fixed in 4\% paraformaldehyde for $30 \mathrm{~min}$ at room temperature. After washing, the cells were permeabilized with $0.2 \%$ Triton X-100 in PBS for 5 min. The cells were rinsed and incubated with the biotinylated nucleotides and the enzyme Terminal deoxynucleotidyl Transferase (TdT) for $1 \mathrm{~h}$ at $37{ }^{\circ} \mathrm{C}$. Cells were rinsed to remove unincorporated nucleotides and endogenous peroxidases were blocked with $0.3 \%$ hydrogen peroxide for $5 \mathrm{~min}$ at room temperature. Cells were then incubated with HRP-labeled streptavidin for $30 \mathrm{~min}$. The HRP was reacted with 3,3'-diaminobenzidine tetrahydrochloride and hydrogen peroxide to develop a brown precipitate that was easily observed in cell cultures. Cells were then washed several times with deionized water, air-dried for $24 \mathrm{~h}$ and mounted with Entellan (Merck). The preparations were visualized using a Zeiss Axiovert 200 microscope, and at least 15 random fields were counted in each preparation. Images were acquired with a photomicrograph system (Cool Snap HQ digital camera; Roper Scientific, Tucson, AZ, USA).

\section{Annexin V staining}

Annexin V binds with high affinity to phosphatidylserine (PS), which becomes exposed on the outer leaflet of the plasma membrane during apoptosis. Annexin V staining was performed with a kit from BD Biosciences Clontech (San Jose, CA, USA) following the instructions provided by the manufacturer. Briefly, cells were rinsed and then incubated with Annexin V-FITC $(20 \mu \mathrm{g} / \mathrm{ml}$ in Tris- $\mathrm{NaCl})$ for $10 \mathrm{~min}$ in the dark at room temperature. Cells were washed and mounted on a glass slide. The preparations were visualized with a Zeiss Axioshop 2 Plus microscope, and for each preparation, at least 5 random fields were counted.

\section{Caspase-3-like enzymes activity assessment}

Caspase- 3 activity was measured in retinal neural cell cultures using Z-Asp-Glu-Val-Asp-AFC (Z-DEVD-AFC), a cell-permeant substrate for caspase-3, which causes a shift in fluorescence upon cleavage of the AFC fluorophore.

The cells were washed and then lysed at $4{ }^{\circ} \mathrm{C}$ in $50 \mathrm{mM} \mathrm{KCl}$, $50 \mathrm{mM}$ PIPES, $10 \mathrm{mM}$ EGTA, $2 \mathrm{mM} \mathrm{MgCl} 2,0.5 \%$ Triton X-100, supplemented with $100 \mu \mathrm{M}$ phenylmethylsulfonyl fluoride (PMSF), $1 \mathrm{mM}$ dithiothreitol (DTT), $1 \mu \mathrm{g} / \mathrm{ml}$ chymostatin, $1 \mu \mathrm{g} /$ $\mathrm{ml}$ leupeptin, $1 \mu \mathrm{g} / \mathrm{ml}$ antiparin, $1 \mu \mathrm{g} / \mathrm{ml}$ pepstatin $\mathrm{A}, \mathrm{pH} 7.4$, at $4{ }^{\circ} \mathrm{C}$. Retinal neural cell lysates were frozen three times in liquid nitrogen, and centrifuged at $15800 \times \mathrm{g}$ for $10 \mathrm{~min}$ at $4{ }^{\circ} \mathrm{C}$. The supernatant was collected and the protein concentration was determined by the Bradford/Bio-Rad method. To measure caspase activity, $20 \mu \mathrm{g}$ of protein were incubated with $100 \mu \mathrm{M}$ DEVD-AFC in reaction buffer $(25 \mathrm{mM}$ HEPES, 0.1\% (w/v) 3-[(3-cholamidopropyl) dimethylammonio]-1-propane-sulfonate (CHAPS), $10 \mathrm{mM}$ DTT, $100 \mu \mathrm{M}$ PMSF) for $30 \mathrm{~min}$ at $37^{\circ} \mathrm{C}$. The reaction was stopped with ice-cold reaction buffer. The fluorescence was monitored with a Spex Fluoromax spectrofluorometer, with excitation at $420 \mathrm{~nm}$ and emission at $505 \mathrm{~nm}$ with a band pass of $5 \mathrm{~nm}$. Caspase-3-like enzymes activity was expressed as the percentage of the control for equal protein loading.

Poly-caspase activation detection with fluorochrome-labeled inhibitors of caspases (FLICA)

Activation of caspases was detected with FAM-VAD-FMK, which is a carboxyfluorescein (FAM) derivative of valylalanylaspartic acid (VAD) fluoromethyl ketone (FMK), a potent inhibitor of caspase activity. Because FAM-VAD-FMK irreversibly binds to several activated caspases (caspase-1, $-3,-4,-5,-6,-7,-8$ and -9), it can be used as a generic probe for the detection of most caspases (Grabarek and Darzynkiewicz, 2002).

Activated caspases were detected with a kit from Immunochemistry Technologies, LCC (Bloomington, MN, USA), according to the instructions provided. Briefly, cells were incubated with FAM-VADFMK for $1 \mathrm{~h}$ at $37^{\circ} \mathrm{C}$ in the dark. Cells were washed, stained with Hoechst 33342 dye $(2 \mu \mathrm{g} / \mathrm{ml})$ for $5 \mathrm{~min}$ and then mounted on a glass slide. Cells with active caspases were visualized in a fluorescent Zeiss Axioshop 2 Plus microscope, and for each preparation, 5 to 8 random fields were counted.

\section{Preparation of mitochondrial, cytosolic and nuclear fractions}

Cells were washed in ice-cold sucrose buffer, containing (in $\mathrm{mM}$ ) 250 sucrose, 20 HEPES/KOH (pH 7.4), 1 EGTA, and 1 EDTA. Cell extracts were obtained in ice-cold sucrose buffer supplemented with $1 \mathrm{mM}$ DTT, $100 \mu \mathrm{M}$ PMSF, $1 \mu \mathrm{g} / \mathrm{ml}$ chymostatin, $1 \mu \mathrm{g} / \mathrm{ml}$ leupeptin, $1 \mu \mathrm{g} / \mathrm{ml}$ antiparin, and $1 \mu \mathrm{g} / \mathrm{ml}$ pepstatin A. Lysates were homogenized and centrifuged $\left(4^{\circ} \mathrm{C}\right)$ at $500 \times g$ for $12 \mathrm{~min}$ to pelletize the nucleus and cell debris. The supernatant (total fraction) was further centrifuged at $12000 \times \mathrm{g}$ for $20 \mathrm{~min}$. The resulting pellet (mitochondrial fraction) was resuspended in supplemented sucrose buffer and the samples were stored at $-80{ }^{\circ} \mathrm{C}$ until use. Trichloroacetic acid (15\%) was added to the supernatant and centrifuged at $15800 \times g$ for $10 \mathrm{~min}$. The resulting pellet (cytosolic fraction) was resuspended in supplemented sucrose buffer and brought to $\mathrm{pH} 7$ with $\mathrm{KOH}$. The samples were stored at $-80^{\circ} \mathrm{C}$ until use.

Preparation of nuclear extracts was carried out as described previously (Levrand et al., 2005), with some modifications, as follows. Cells were washed in ice-cold PBS and cell extracts were obtained with buffer A (10 mM HEPES (pH 7.9), $10 \mathrm{mM} \mathrm{KCl}$, $0.1 \mathrm{mM}$ EDTA) supplemented with $1 \mathrm{mM}$ DTT and $0.4 \%$ Nonidet $\mathrm{P}-40$. The lysates were placed on ice for $30 \mathrm{~min}$ and then centrifuged at $15800 \times g$ for $5 \mathrm{~min}$ at $4{ }^{\circ} \mathrm{C}$. The pellet was resuspended in buffer B (20 mM HEPES (pH 7.9), $400 \mathrm{mM} \mathrm{NaCl}$, $1 \mathrm{mM}$ EDTA) supplemented with $1 \mathrm{mM} \mathrm{DTT}$ and 10\% glycerol, and incubated for $60 \mathrm{~min}$ on ice. Then, the samples were sonicated and centrifuged at $15800 \times \mathrm{g}$ for $5 \mathrm{~min}$ at $4{ }^{\circ} \mathrm{C}$. The supernatant containing the nuclear fraction was collected, and then stored at $-80{ }^{\circ} \mathrm{C}$ until use.

\section{Western blot analysis}

Protein concentration was determined by the Bradford/Bio-Rad method, and equivalent amounts of protein (50 $\mu \mathrm{g}$ for caspase-3 detection from cytosolic fraction; and $40 \mu \mathrm{g}$ or $15 \mu \mathrm{g}$ for AIF detection from mitochondrial fraction or nuclear fraction, respec- 


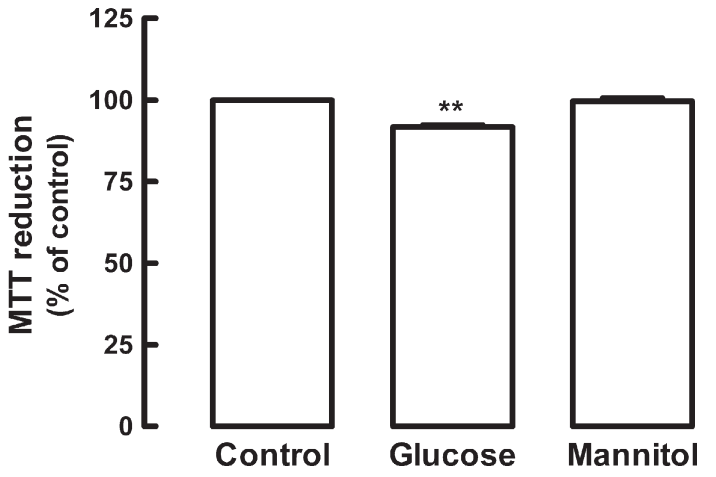

Fig. 1. Elevated glucose decreases cell viability. Rat primary retinal neural cell cultures were incubated in $5 \mathrm{mM}$ glucose (Control), $30 \mathrm{mM}$ glucose (Glucose) or $25 \mathrm{mM}$ mannitol (Mannitol) for 7 days. The results represent the mean \pm SEM of at least 14 independent experiments performed in triplicate, and are presented as percentage of control. ${ }^{* *} p<0.01$, significantly different from control; one-way ANOVA followed by Dunnett's post-hoc test.

tively) were used for Western blot analysis, after adding $6 \times$ concentrated sample buffer $(0.5 \mathrm{M}$ Tris, $30 \%$ glycerol, $10 \%$ SDS, $0.6 \mathrm{M}$ DTT, $0.012 \%$ bromophenol blue) and heating the samples for $5 \mathrm{~min}$ at $95{ }^{\circ} \mathrm{C}$. Proteins were separated on $7.5-12 \%$ sodium dodecyl sulphate-polyacrylamide gel electrophoresis (SDSPAGE), and transferred electrophoretically to PVDF membranes. The membranes were blocked for $1 \mathrm{~h}$ at room temperature, in Trisbuffered saline (in mM: $137 \mathrm{NaCl}, 20$ Tris-HCl; $\mathrm{pH}$ 7.6) containing $0.1 \%$ Tween-20 (TBS-T) and 5\% skimmed milk. The membranes were incubated with the antibodies directed against the denatured form of caspase-3 (1:1000) or AIF (1:1000), overnight at $4{ }^{\circ} \mathrm{C}$. To control for protein loading, the membranes were probed with a mouse anti- $\alpha$-tubulin (1:3 000) or with a mouse anti-lamin B (1:60).

After washing for $1 \mathrm{~h}$ in TBS-T with $0.5 \%$ skimmed milk, the membranes were incubated for $1 \mathrm{~h}$ at room temperature with an alkaline phosphatase-linked secondary antibody (anti-mouse IgG, 1:20,000 in TBS-T with $1 \%$ skimmed milk). The membranes were processed for detection of AIF using the ECF system on the Versa Doc Imaging System and the quantification was performed using Quantity One software (Bio-Rad).

\section{Immunocytochemistry}

Cells were washed twice with PBS and fixed with 4\% paraformaldehyde with $4 \%$ sucrose for $10 \mathrm{~min}$ at room temperature. Cells were rinsed twice in PBS and then permeabilized with $1 \%$ Triton X-100 in PBS for 5 min. After blocking for $1 \mathrm{~h}$ with $3 \%$ BSA plus $0.2 \%$ Tween 20 in PBS, cells were incubated with the primary antibody (anti-MAP2, 1:500 and/or anti-AIF, 1:100) for $90 \mathrm{~min}$. Cells were rinsed three times with the blocking solution and incubated with Alexa 488-conjugated secondary antibody (goat anti-mouse IgG, 1:200) and/or Alexa 594-conjugated secondary antibody (goat anti-rabbit IgG, 1:200). The nuclei were stained with $2 \mu \mathrm{g} / \mathrm{ml}$ Hoechst 33342 in PBS for 5 min. The preparations labeled with anti-MAP2 and anti-AIF antibodies were visualized with a Bio-Rad MRC 600 confocal microscope, and the preparations labeled only with anti-AIF antibody and stained with Hoechst 33342 were visualized with a Leica DM IRE2 epifluorescent microscope.

\section{Data analysis}

Data are expressed as means \pm SEM. Statistical significance was determined by analysis of variance (ANOVA), followed by Dunnett's post-hoc test.

\section{Results}

\section{Elevated glucose concentration decreases retinal neural cell viability}

Retinal neural cells were exposed to $30 \mathrm{mM}$ glucose or $25 \mathrm{mM}$ mannitol (plus $5 \mathrm{mM}$ glucose) and cultured for 7 days in these conditions. In control cultures, initial glucose concentration was $5 \mathrm{mM}$. The concentration of glucose in the extracellular medium after 7 days was $2.6 \pm 0.6 \mathrm{mM}, 27.9 \pm 0.5 \mathrm{mM}$ and $2.9 \pm 0.6 \mathrm{mM}$ in control, high glucose- and mannitol-treated cells, respectively.

The exposure of retinal neural cells to $30 \mathrm{mM}$ glucose for 7 days caused a significant decrease in cell viability, as assessed by the MTT assay (Fig. 1). In high glucose-treated cells there was a decrease in MTT reduction to $91.7 \pm 0.6 \%$ of the control. The exposure to mannitol, which was used as osmotic control, did not cause a significant decrease in MTT reduction $(99.6 \pm 0.9 \%$ of the control).

Depletion in ATP levels is usually associated with cell death by necrosis. Intracellular ATP levels were determined in cell extracts by HPLC. There were no significant changes in the levels of intracellular ATP in the three conditions (Fig. 2). In control cells, ATP levels were $57.1 \pm 2.6 \mathrm{nmol} / \mathrm{mg}$ protein and in high glucose- and mannitol-treated cells ATP levels were $53.7 \pm 4.9 \mathrm{nmol} / \mathrm{mg}$ protein and $54.3 \pm 6.8 \mathrm{nmol} / \mathrm{mg}$ protein, respectively.

\section{Elevated glucose causes cell death in retinal neural cells}

To evaluate whether a decrease in cell viability, as assessed by the MTT method, was related with an increase in cell death, we examined nuclear morphology of cultured retinal neural cells using the Hoechst 33342 dye that allows the assessment of chromatin alterations (Fig. 3). In control cells the percentage of apoptotic cells, with condensed and/or fragmented chromatin, was $3.2 \pm 0.5 \%$. In high glucose-treated cells there was a significant increase of apoptotic cells $(7.9 \pm 1.2 \%)$. This effect was not due to the increase in osmolarity, since incubation with mannitol resulted in a similar

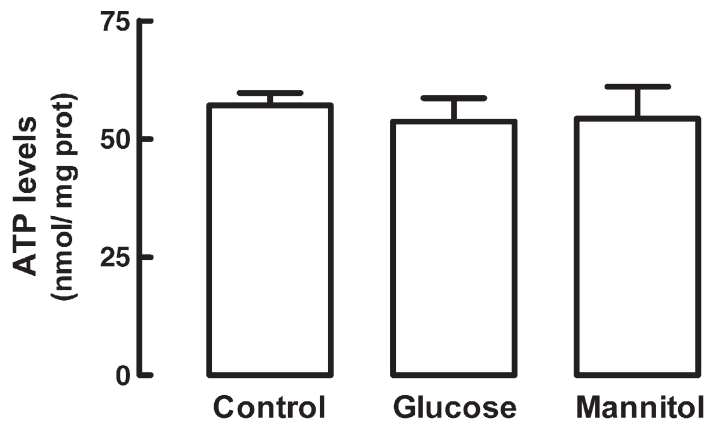

Fig. 2. Elevated glucose does not change intracellular ATP levels. Rat primary retinal neural cell cultures were incubated in $5 \mathrm{mM}$ glucose (Control), $30 \mathrm{mM}$ glucose (Glucose) or $25 \mathrm{mM}$ mannitol (Mannitol) for 7 days. The results are presented as the mean \pm SEM of five independent experiments. 


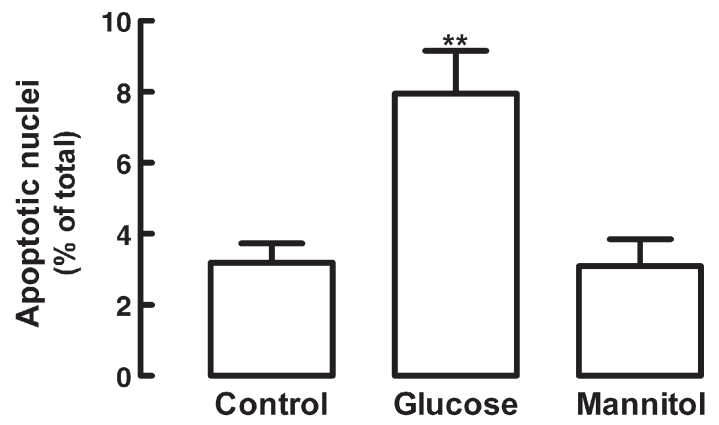

Fig. 3. Elevated glucose increases the number of cells with condensed and/or fragmented chromatin. Rat primary retinal neural cell cultures were incubated in $5 \mathrm{mM}$ glucose (Control), $30 \mathrm{mM}$ glucose (Glucose) or $25 \mathrm{mM}$ mannitol (Mannitol) for 7 days. The results represent the mean \pm SEM of at least three independent experiments, and are expressed as the percentage of total cells. ${ }^{* *} p<0.01$, significantly different from control; oneway ANOVA followed by Dunnett's post-hoc test.

number of cells with condensed and/or fragmented chromatin, as compared to the control (3.1 $\pm 0.8 \%$ of apoptotic cells).

We also measured nuclear DNA fragmentation, an important feature of apoptosis, by using the TUNEL assay (Fig. 4). In control conditions, $5.3 \pm 0.7$ TUNEL-positive cells/field were counted, and this value increased to $10.8 \pm 1.2$ TUNEL-positive cells/field when cells were exposed to high glucose, corresponding to $202.8 \pm 34.4 \%$ relatively to the control. In mannitol-treated cells the number of positive cells was similar to the control $(4.7 \pm 0.7$ TUNEL-positive cells/field).

The exposure of the phospholipid phosphatidylserine (PS) on the outer leaflet of the plasma membrane occurs in cells undergoing apoptosis (Vermes et al., 2000). Because the anticoagulant protein annexin $\mathrm{V}$ binds with high affinity to PS, the fluorochrome-tagged annexin $\mathrm{V}$ is frequently used as a marker of apoptosis (Vermes et al., 2000). In control cells, $7.0 \pm 0.6$ cells/field were annexin V-positive. Incubation with $30 \mathrm{mM}$ glucose for 7 days significantly increased the number of annexin V-positive cells ( $10.5 \pm 1.2$ cells/field), which represents an increase of $149.7 \pm 16.7 \%$ of the control. Mannitol did not change the number of annexin V-positive cells, as compared to the control $(5.6 \pm 0.4$ cells/field $)$, indicating that these changes were not due to increases in osmolarity (Fig. 5).

\section{High glucose-induced cell death is independent of caspase activation}

Since an increase in cell death could be due to an increase in caspase activity, we investigated whether elevated glucose caused an increase in caspase-3-like enzymes activity. As shown in Fig. 6A, there were no significant changes in the activity of caspase-3 among the conditions tested $(99.3 \pm 5.6 \%$ of the control, in high glucosetreated cells). In addition, we also determined whether other caspases were being activated by elevated glucose concentration exposure. FAM-VAD-FMK, a fluorescent inhibitor of caspase-1, -3, $-4,-5,-6,-7,-8$ and -9 , irreversibly binds to activated caspases. Using this probe, cells with active caspases were visualized under a fluorescent microscope (Fig. 6B). In control cells, $13.3 \pm 2.9$ cells/ field had active caspases, and the exposure of cells to high glucose did not cause significant changes compared to the control $(12.1 \pm$ 2.6 positive cells/field), showing that elevated glucose did not induce caspase activation. In mannitol-treated cells the number of FAM-VAD-FMK-positive cells was similar to the control $(12.1 \pm$ 1.1 cells). In the presence of staurosporine ( $90 \mathrm{nM}, 3 \mathrm{~h})$, used as a positive control of caspase activation (Lopez and Ferrer, 2000), both

A
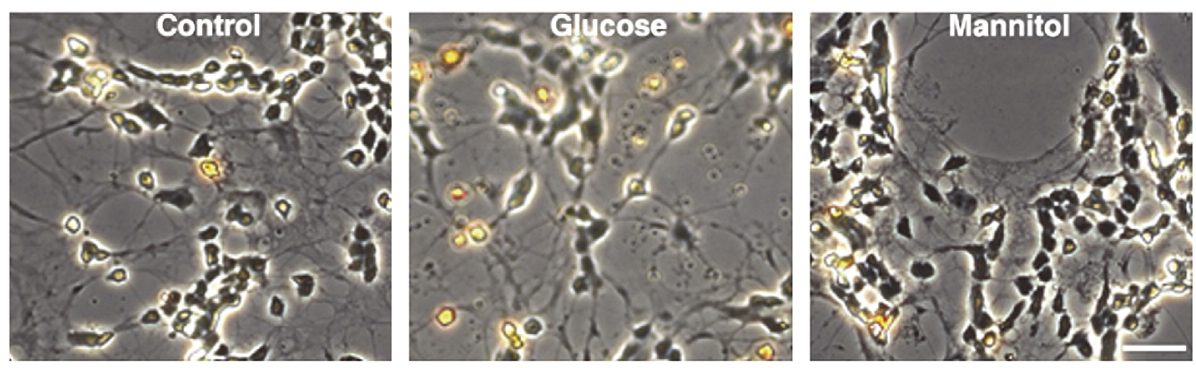

B

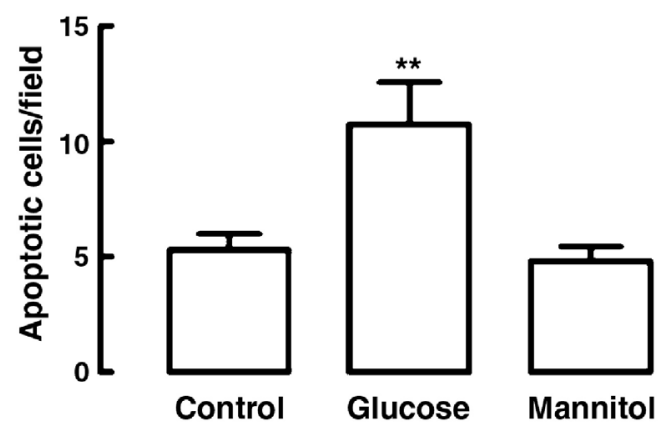

Fig. 4. Elevated glucose increases TUNEL-positive cells. Rat primary retinal neural cell cultures were incubated in $5 \mathrm{mM}$ glucose (Control), $30 \mathrm{mM}$ glucose (Glucose) or $25 \mathrm{mM}$ mannitol (Mannitol) for 7 days. Cells were labeled by the TUNEL assay. The results represent the mean \pm SEM of at least three independent experiments, and are expressed as the number of TUNEL-positive cells per field. Pictures in A are representative of each condition tested. ${ }^{* *} p<0.01$, significantly different from control; one-way ANOVA followed by Dunnett's post-hoc test. Bar: $20 \mu \mathrm{m}$. 


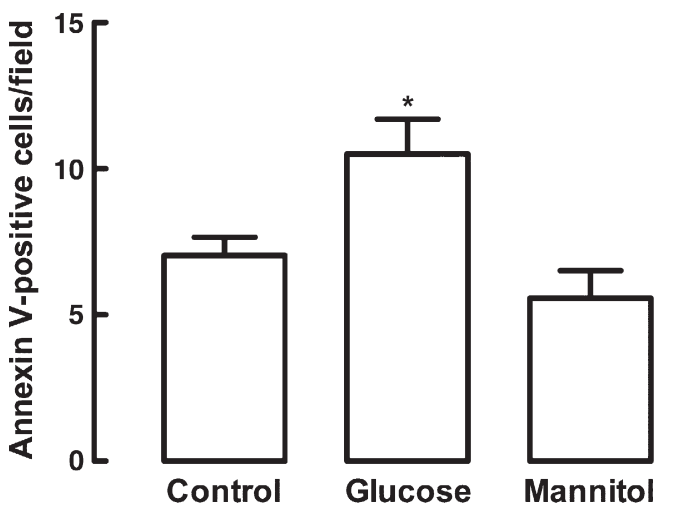

Fig. 5. Elevated glucose enhances phosphatidylserine translocation to the outer leaflet of plasma membrane. Rat primary retinal neural cell cultures were incubated in $5 \mathrm{mM}$ glucose (Control), $30 \mathrm{mM}$ glucose (Glucose) or $25 \mathrm{mM}$ mannitol (Mannitol) for 7 days. The results represent the mean \pm SEM of at least six independent experiments, and are expressed as the number of annexin V-positive cells per field. ${ }^{*} p<0.05$, significantly different from control; one-way ANOVA followed by Dunnett's post-hoc test.

the activity of caspase- 3 and the number of FAM-VAD-FMKpositive cells were increased (Figs. 6A and B). Also, by Western blot analysis we did not detect the large fragment of caspase-3 (17 kDa) resulting from proteolytic cleavage of pro-caspase-3 (Fig. 6C), confirming the previous results.

To further understand the mechanism by which elevated glucose caused an increase in the number of apoptotic cells, without inducing caspase activation, we checked whether apoptosis-inducing factor (AIF) could be involved. By Western blot analysis we found that the protein levels of mitochondrial AIF significantly decreased in high glucose-treated cells $(75.9 \pm 3.9 \%$ of the control; Fig. 7A). Concomitantly, in the nuclear fraction, AIF was increased in high glucose-treated cells $(136.1 \pm 15.3 \%$ of the control) compared to the control (Fig. 7B). In mannitol-treated cells there were no changes, comparing to the control. By immunocytochemistry, we observed that in control conditions AIF was mainly found in the perinuclear region, and the immunoreactivity of AIF increased in the nuclei of high glucosetreated cells (Fig. 7C), confirming the results obtained by Western blotting.

\section{Discussion}

In this study, we demonstrate for the first time that elevated glucose concentration causes caspase-independent cell death in cultured retinal neural cells.

Since hyperglycemia is considered the primary pathogenic factor in the development of DR, we used an in vitro model to mimic hyperglycemic conditions occurring in diabetes. Although usually considered a vascular disease, cumulative evidences show that DR presents characteristics of neurodegenerative diseases. Several reports show that retinal neurons undergo apoptosis upon diabetes (Abu-El-Asrar et al., 2004; Martin et al., 2004; Barber et al., 2005), which may be triggered by caspase-3 activation (Mohr et al., 2002). There are few reports showing the involvement of caspaseindependent cell death in the retina, but they are not related with DR (Hisatomi et al., 2001; Tezel and Yang, 2004; Zanna et al., 2005). Our results are the first reporting the involvement of caspaseindependent apoptosis in an in vitro model of DR.
Under the present experimental conditions, we found that elevated glucose concentration decreases cell viability, without changes in the intracellular levels of ATP. These results suggest that necrosis is not involved, since there are evidences that cells are forced
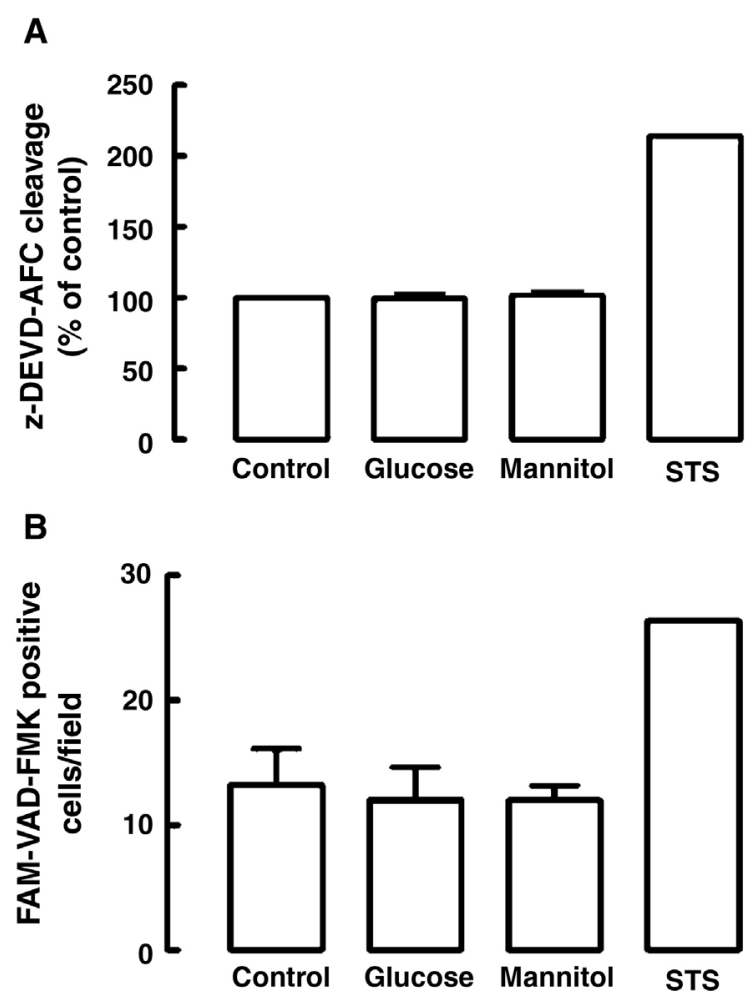

C

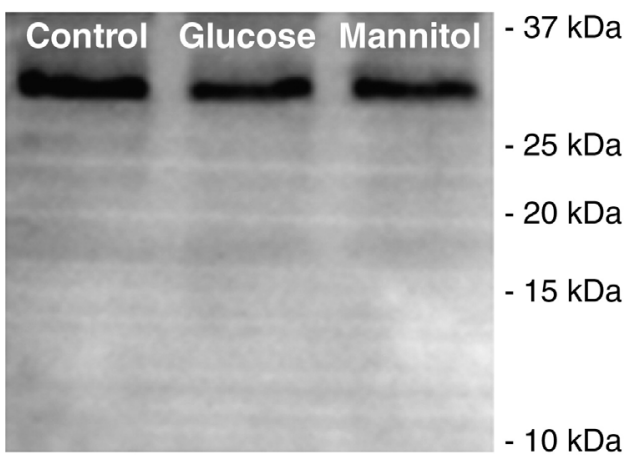

Fig. 6. Elevated glucose does not cause caspase activation. Rat primary retinal neural cell cultures were incubated in $5 \mathrm{mM}$ glucose (Control), $30 \mathrm{mM}$ glucose (Glucose) or $25 \mathrm{mM}$ mannitol (Mannitol) for 7 days. (A) The activity of caspase-3-like enzymes does not increase in high glucose-treated cells. Caspase-3-like enzymes activity was determined with Z-DEVD-AFC, a fluorescent substrate for caspase-3-like enzymes. The results represent the mean $\pm \mathrm{SEM}$ of at least eight independent experiments and are expressed as percentage of control. (B) The number of cells with active caspase-1, -3, -4, $-5,-6,-7,-8$ and -9 did not change with elevated glucose levels. Cells were incubated with FAM-VAD-FMK. The results represent the mean \pm SEM of at least six independent experiments, and are expressed as the number of FAMVAD-FMK-positive cells per field. (C) The large fragment of caspase-3 (17 kDa), resulting from proteolytic cleavage of pro-caspase-3, was not detected by Western blot analysis. Staurosporine (STS; $90 \mathrm{mM}$ ) was used as positive control for caspase activation. 
A

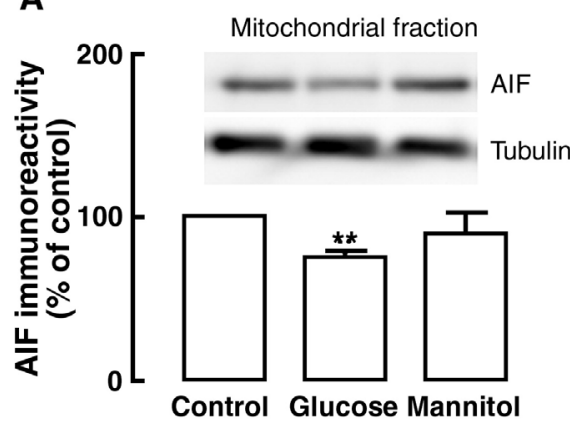

B

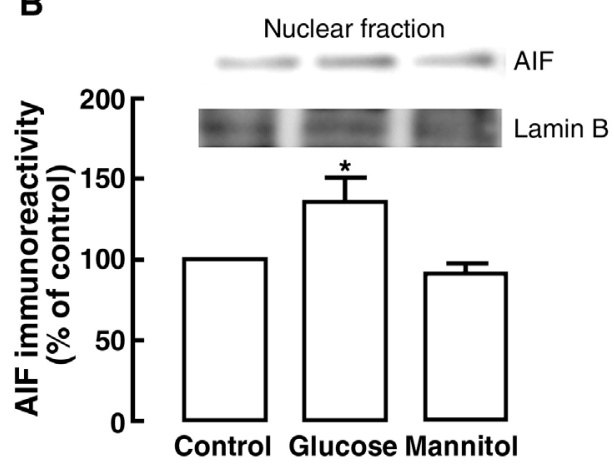

C
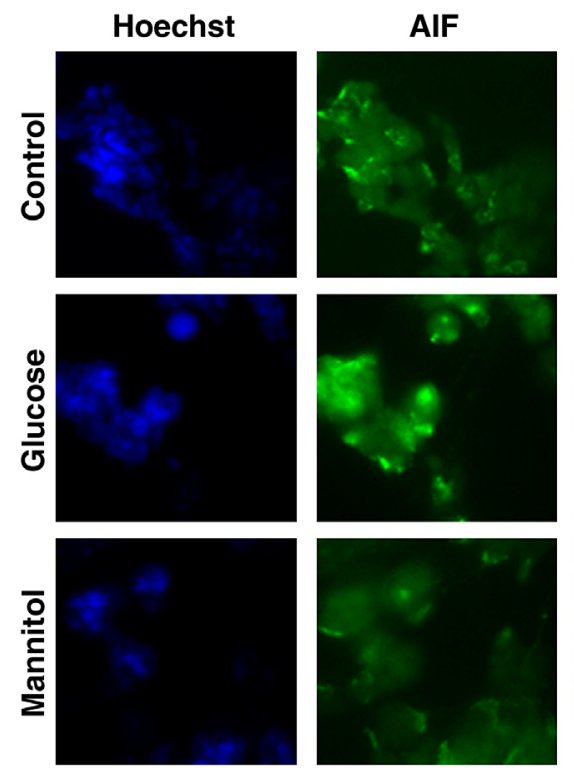
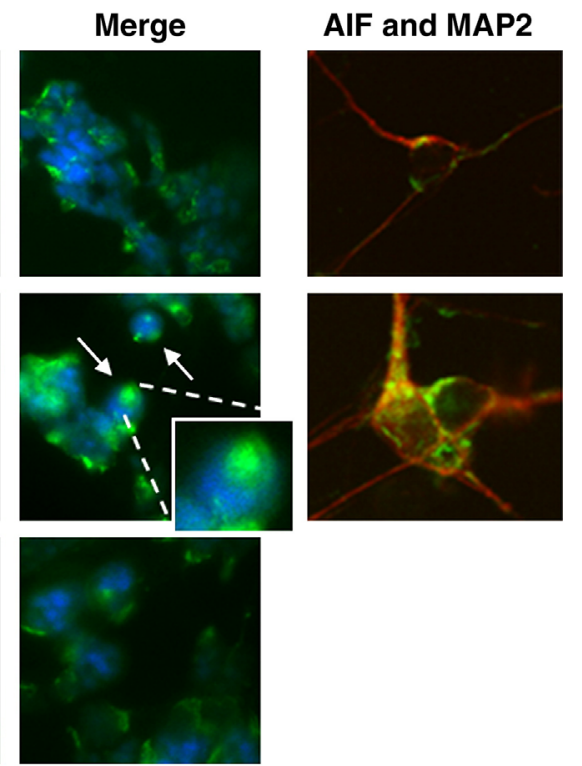

Fig. 7. Elevated glucose triggers AIF translocation from the mitochondria to the nucleus. Rat primary retinal neural cell cultures were incubated in $5 \mathrm{mM}$ glucose (Control), $30 \mathrm{mM}$ glucose (Glucose) or $25 \mathrm{mM}$ mannitol (Mannitol) for seven days. Mitochondrial (A) and nuclear (B) extracts of cultured retinal neural cells were assayed for AIF. Representative Western blots are presented above the graphs. The densitometry of each band was analyzed and the results are expressed as percentage of control \pm SEM of at least three independent experiments. Representative Western blots for AIF, $\alpha$-tubulin and lamin B are shown. (C) Subcellular localization of AIF was analyzed by immunocytochemistry using an antibody against AIF (green), the nuclear marker Hoechst 33342 (blue) and MAP2 (red). Arrows indicate the presence of AIF in the nucleus. ${ }^{*} p<0.05,{ }^{* *} p<0.01$, significantly different from control; one-way ANOVA followed by Dunnett's post-hoc test.

to dye by necrosis when intracellular ATP is depleted (McConkey, 1998). Conversely, we have found that retinal neural cells exposed to high glucose are dying by apoptosis, confirming the results previously found in diabetic retinas (Abu-El-Asrar et al., 2004; Martin et al., 2004; Barber et al., 2005). High glucose increased nuclear condensation, DNA fragmentation and the exposure of annexin $V$ on the outer leaflet of cell membranes, which are apoptotic features. However, it is important to mention that long-term exposure to high glucose did not cause a widespread neural degeneration in retinal neural cells. The percentage of cells undergoing apoptosis was about $10 \%$ (about $5 \%$ in control conditions). Mannitol, the osmotic control, did not increase apoptosis, indicating that apoptosis was not due to the increase in osmolarity.

Caspase- 3 is an executioner caspase, acting downstream death signals and other caspases activation. We did not observe an increase in the activity of caspase-3 nor an increase in activation of other caspases, suggesting that in these conditions the increase in cell death was not due to caspase activation.

Usually considered a marker for caspase-dependent cell death, the appearance of phosphatidylserine in the outer leaflet of the plasma membrane (Martin et al., 1996) can also occur independent of caspase activation (Andersson et al., 2000), which corroborates our findings of increased annexin V-positive cells in high glucosetreated cells without activation of caspases. Although caspasemediated apoptosis is the main form of cell death, much evidence now shows that caspase-independent pathways are as just important (Leist and Jaattela, 2001).
Mitochondria have a key role in the control of cell death (Kroemer and Reed, 2000). Cytochrome $c$ release from the mitochondria leads to caspase activation and neuronal apoptosis. In addition, several other mediators, such as AIF and endonuclease $\mathrm{G}$, may be released from mitochondria and play a role in cell death (Susin et al., 1999; Li et al., 2001).

AIF is synthesized as a nonapoptogenic precursor in the cytoplasm and then imported to the mitochondrial intermembrane space. In physiological conditions, it is present in the intermembrane space of mitochondria, which, upon cytotoxic stimuli, can be translocated to the nucleus, via the cytosol (Susin et al., 1999). In the nucleus, AIF can induce large-scale ( $\sim 50 \mathrm{kbp})$ DNA fragmentation (Daugas et al., 2000). AIF translocation is independent of caspase activation and is also able to cause the exposure of phosphatidylserine on the surface of plasma membrane, as was demonstrated previously (Susin et al., 1999).

A sustained increase in intracellular calcium concentration $\left(\left[\mathrm{Ca}^{2+}\right]_{\mathrm{i}}\right)$ is known to cause cell dysfunction and death (Duchen, 2004). We have recently shown that calcium homeostasis is affected in retinal neural cells incubated with high glucose (Santiago et al., 2006a). The changes in the $\left[\mathrm{Ca}^{2+}\right]_{\mathrm{i}}$, induced by membrane depolarization or by activation of ionotropic glutamate receptors, are higher in high glucose-treated cells. We have also shown that the recovery to basal $\mathrm{Ca}^{2+}$ levels is delayed in these cells. This $\left[\mathrm{Ca}^{2+}\right]_{i}$ increase can induce mitochondrial membrane permeabilization, causing the release of soluble intermembrane proteins through the outer mitochondrial membrane. In fact, observations showing the 
release of AIF and endonuclease G from mitochondria, associated with the disruption of mitochondrial membrane potential, have been published previously (Bains et al., 2003; Davies et al., 2003). Moreover, it was already reported that conditions of altered calcium homeostasis induce the release of AIF from the mitochondria (Braun et al., 2002; Lemarie et al., 2004; Vindis et al., 2005).

Recently, it was reported that AIF is increased in the retina of patients with diabetes (Abu El-Asrar et al., 2006). In this study, the authors examined, by immunohistochemistry, postmortem eyes from patients with diabetes and found an increase in the levels of AIF in the inner segments of photoreceptors, in the inner one-third of the outer plexiform layer, in cells in the inner nuclear layer, in the inner plexiform layer, and in ganglion cells. However, this study fails to demonstrate a translocation of AIF, which is necessary to trigger cell death. Several studies demonstrated the role of AIF in mediating cell death upon retinal detachment or experimental hypoxia of retinal ganglion cells in culture (Hisatomi et al., 2001; Tezel and Yang, 2004). Here, we showed that AIF translocates from the mitochondria to the nucleus, which may explain the increase in cell death.

In summary, we show that elevated glucose causes cell death in retinal neural cells, supporting previous findings of neurodegeneration in DR. However, cell death was independent of caspase activation and may be mediated by the translocation of AIF to the nucleus.

Identifying the upstream signal that leads to AIF release is an important goal, so as the understanding of the mechanisms that cause cell death in the diabetic retina. The fact that blocking the effect of AIF with neutralizing antibodies decreases neuronal injury (Cregan et al., 2002) suggests that AIF may be used as a therapeutic target.

Considering our results and those of others, neuroprotective strategies to prevent vision loss in diabetic patients should not only take into account the mechanisms of apoptosis mediated by caspases but also those of caspase-independent cell death in order to improve the ability of retinal neurons to survive.

\section{Acknowledgments}

This work was supported by the Foundation for Science and Technology, Portugal (POCTI/CBO/38545/01) and FEDER.

\section{References}

Abu-El-Asrar, A.M., Dralands, L., Missotten, L., Al-Jadaan, I.A., Geboes, K., 2004. Expression of apoptosis markers in the retinas of human subjects with diabetes. Invest. Ophthalmol. Visual Sci. 45, 2760-2766.

Abu El-Asrar, A.M., Dralands, L., Missotten, L., Geboes, K., 2006. Expression of antiapoptotic and proapoptotic molecules in diabetic retinas. Eye. doi:10.1038/sj.eye.6702225.

Andersson, M., Sjostrand, J., Petersen, A., Honarvar, A.K., Karlsson, J.O., 2000. Caspase and proteasome activity during staurosporin-induced apoptosis in lens epithelial cells. Invest. Ophthalmol. Visual Sci. 41, 2623-2632.

Bains, S.K., Mone, A., Yun Tso, J., Lucas, D., Byrd, J.C., Weiner, G.J., Green, J.M., 2003. Mitochondria control of cell death induced by antiHLA-DR antibodies. Leukemia 17, 1357-1365.

Barber, A.J., Lieth, E., Khin, S.A., Antonetti, D.A., Buchanan, A.G., Gardner, T.W., 1998. Neural apoptosis in the retina during experimental and human diabetes. Early onset and effect of insulin. J. Clin. Invest. 102, 783-791.

Barber, A.J., Antonetti, D.A., Kern, T.S., Reiter, C.E., Soans, R.S., Krady, J.K., Levison, S.W., Gardner, T.W., Bronson, S.K., 2005. The Ins2Akita mouse as a model of early retinal complications in diabetes. Invest. Ophthalmol. Visual Sci. 46, 2210-2218.
Borner, C., Monney, L., 1999. Apoptosis without caspases: an inefficient molecular guillotine? Cell Death Differ. 6, 497-507.

Braun, J.S., Sublett, J.E., Freyer, D., Mitchell, T.J., Cleveland, J.L., Tuomanen, E.I., Weber, J.R., 2002. Pneumococcal pneumolysin and $\mathrm{H}(2) \mathrm{O}(2)$ mediate brain cell apoptosis during meningitis. J. Clin. Invest. $109,19-27$.

Cai, J., Boulton, M., 2002. The pathogenesis of diabetic retinopathy: old concepts and new questions. Eye 16, 242-260.

Cregan, S.P., Fortin, A., MacLaurin, J.G., Callaghan, S.M., Cecconi, F., Yu, S.W., Dawson, T.M., Dawson, V.L., Park, D.S., Kroemer, G., Slack, R.S., 2002. Apoptosis-inducing factor is involved in the regulation of caspaseindependent neuronal cell death. J. Cell Biol. 158, 507-517.

Daugas, E., Susin, S.A., Zamzami, N., Ferri, K.F., Irinopoulou, T., Larochette, N., Prevost, M.C., Leber, B., Andrews, D., Penninger, J., Kroemer, G., 2000. Mitochondrio-nuclear translocation of AIF in apoptosis and necrosis. FASEB J. 14, 729-739.

Davies, A.M., Hershman, S., Stabley, G.J., Hoek, J.B., Peterson, J., Cahill, A., 2003. $\mathrm{A} \mathrm{Ca}^{2+}$-induced mitochondrial permeability transition causes complete release of rat liver endonuclease $\mathrm{G}$ activity from its exclusive location within the mitochondrial intermembrane space. Identification of a novel endo-exonuclease activity residing within the mitochondrial matrix. Nucleic Acids Res. 31, 1364-1373.

Duchen, M.R., 2000. Mitochondria and calcium: from cell signalling to cell death. J. Physiol. 529 (Pt 1), 57-68.

Duchen, M.R., 2004. Roles of mitochondria in health and disease. Diabetes 53 (Suppl. 1), S96-S102.

Grabarek, J., Darzynkiewicz, Z., 2002. In situ activation of caspases and serine proteases during apoptosis detected by affinity labeling their enzyme active centers with fluorochrome-tagged inhibitors. Exp. Hematol. 30, 982-989.

Hisatomi, T., Sakamoto, T., Murata, T., Yamanaka, I., Oshima, Y., Hata, Y., Ishibashi, T., Inomata, H., Susin, S.A., Kroemer, G., 2001. Relocalization of apoptosis-inducing factor in photoreceptor apoptosis induced by retinal detachment in vivo. Am. J. Pathol. 158, 1271-1278.

Krady, J.K., Basu, A., Allen, C.M., Xu, Y., LaNoue, K.F., Gardner, T.W., Levison, S.W., 2005. Minocycline reduces proinflammatory cytokine expression, microglial activation, and caspase- 3 activation in a rodent model of diabetic retinopathy. Diabetes 54, 1559-1565.

Kroemer, G., Reed, J.C., 2000. Mitochondrial control of cell death. Nat. Med. 6, 513-519.

Lavoie, J.N., Nguyen, M., Marcellus, R.C., Branton, P.E., Shore, G.C., 1998. E4orf4, a novel adenovirus death factor that induces p53-independent apoptosis by a pathway that is not inhibited by zVAD-fmk. J. Cell Biol. 140, 637-645.

Leifer, D., Dreyer, E.B., Lipton, S.A., 1991. Immunofluorescent characterization of retinal ganglion cell neurites cultured on substrates coated with antibodies against Thy-1. Exp. Neurol. 113, 386-390.

Leist, M., Jaattela, M., 2001. Four deaths and a funeral: from caspases to alternative mechanisms. Nat. Rev., Mol. Cell Biol. 2, 589-598.

Lemarie, A., Lagadic-Gossmann, D., Morzadec, C., Allain, N., Fardel, O., Vernhet, L., 2004. Cadmium induces caspase-independent apoptosis in liver Hep3B cells: role for calcium in signaling oxidative stress-related impairment of mitochondria and relocation of endonuclease $\mathrm{G}$ and apoptosis-inducing factor. Free Radical Biol. Med. 36, 1517-1531.

Levrand, S., Pesse, B., Feihl, F., Waeber, B., Pacher, P., Rolli, J., Schaller, M.D., Liaudet, L., 2005. Peroxynitrite is a potent inhibitor of NF-\{kappa\} $\mathrm{B}$ activation triggered by inflammatory stimuli in cardiac and endothelial cell lines. J. Biol. Chem. 280, 34878-34887.

Li, L.Y., Luo, X., Wang, X., 2001. Endonuclease G is an apoptotic DNase when released from mitochondria. Nature 412, 95-99.

Lopez, E., Ferrer, I., 2000. Staurosporine- and H-7-induced cell death in SHSY5Y neuroblastoma cells is associated with caspase-2 and caspase-3 activation, but not with activation of the FAS/FAS-L-caspase-8 signaling pathway. Brain Res. Mol. Brain Res. 85, 61-67.

Lorenzo, H.K., Susin, S.A., Penninger, J., Kroemer, G., 1999. Apoptosis inducing factor (AIF): a phylogenetically old, caspase-independent effector of cell death. Cell Death Differ. 6, 516-524. 
Martin, S.J., Finucane, D.M., Amarante-Mendes, G.P., O'Brien, G.A., Green, D.R., 1996. Phosphatidylserine externalization during CD95induced apoptosis of cells and cytoplasts requires ICE/CED-3 protease activity. J. Biol. Chem. 271, 28753-28756.

Martin, P.M., Roon, P., Van Ells, T.K., Ganapathy, V., Smith, S.B., 2004. Death of retinal neurons in streptozotocin-induced diabetic mice. Invest. Ophthalmol. Visual Sci. 45, 3330-3336.

McConkey, D.J., 1998. Biochemical determinants of apoptosis and necrosis. Toxicol. Lett. 99, 157-168.

Mohr, S., Xi, X., Tang, J., Kern, T.S., 2002. Caspase activation in retinas of diabetic and galactosemic mice and diabetic patients. Diabetes 51, $1172-1179$

Mosmann, T., 1983. Rapid colorimetric assay for cellular growth and survival: application to proliferation and cytotoxicity assays. PG - 55-63. J. Immunol. 65.

Okuno, S., Shimizu, S., Ito, T., Nomura, M., Hamada, E., Tsujimoto, Y., Matsuda, H., 1998. Bcl-2 prevents caspase-independent cell death. J. Biol. Chem. 273, 34272-34277.

Sakai, H., Tani, Y., Shirasawa, E., Shirao, Y., Kawasaki, K., 1995. Development of electroretinographic alterations in streptozotocininduced diabetes in rats. Ophthalmic Res. 27, 57-63.

Santiago, A.R., Rosa, S.C., Santos, P.F., Cristóvão, A.J., Barber, A.J., Ambrósio, A.F., 2006a. Elevated glucose changes the expression of ionotropic glutamate receptor subunits and impairs calcium homeostasis in retinal neural cells. Invest. Ophthalmol. Visual Sci. 47, 4130-4137.

Santiago, A.R., Pereira, T.S., Garrido, M.J., Cristovao, A.J., Santos, P.F., Ambrosio, A.F., 2006b. High glucose and diabetes increase the release of $[(3) \mathrm{H}]-\mathrm{D}$-aspartate in retinal cell cultures and in rat retinas. Neurochem. Int. 48, 453-458.

Stocchi, V., Cucchiarini, L., Magnani, M., Chiarantini, L., Palma, P., Crescentini, G., 1985. Simultaneous extraction and reverse-phase highperformance liquid chromatographic determination of adenine and pyridine nucleotides in human red blood cells. Anal. Biochem. 146 , $118-124$.

Susin, S.A., Lorenzo, H.K., Zamzami, N., Marzo, I., Snow, B.E., Brothers, G.M., Mangion, J., Jacotot, E., Costantini, P., Loeffler, M., Larochette, N., Goodlett, D.R., Aebersold, R., Siderovski, D.P., Penninger, J.M., Kroemer, G., 1999. Molecular characterization of mitochondrial apoptosis-inducing factor. Nature 397, 441-446.

Tezel, G., Yang, X., 2004. Caspase-independent component of retinal ganglion cell death, in vitro. Invest. Ophthalmol. Visual Sci. 45, 4049-4059.

Vermes, I., Haanen, C., Reutelingsperger, C., 2000. Flow cytometry of apoptotic cell death. J. Immunol. Methods 243, 167-190.

Vindis, C., Elbaz, M., Escargueil-Blanc, I., Auge, N., Heniquez, A., Thiers, J.C., Negre-Salvayre, A., Salvayre, R., 2005. Two distinct calciumdependent mitochondrial pathways are involved in oxidized LDLinduced apoptosis. Arterioscler. Thromb. Vasc. Biol. 25, 639-645.

Zanna, C., Ghelli, A., Porcelli, A.M., Martinuzzi, A., Carelli, V., Rugolo, M., 2005. Caspase-independent death of Leber's hereditary optic neuropathy cybrids is driven by energetic failure and mediated by AIF and endonuclease G. Apoptosis 10, 997-1007.

Zou, H., Henzel, W.J., Liu, X., Lutschg, A., Wang, X., 1997. Apaf-1, a human protein homologous to $C$. elegans CED-4, participates in cytochrome $c$-dependent activation of caspase-3. Cell 90, 405-413. 